\title{
Symbiotic Relationship Between Emotional Intelligence And Collegial Leadership
}

\author{
Prakash Singh, Nelson Mandela Metropolitan University, South Africa
}

\begin{abstract}
Research on leadership over the past two decades suggests that the emotional intelligence of leaders matters twice as much as that of cognitive abilities, such as IQ or technical expertise. Emotionally intelligent leaders experience a greater sense of well-being, improved relationships, happier employees and lower employee turnover, better team work, greater job satisfaction and a greater degree of success. Four hundred and seventy four employees participated in this study. The quantitative research method was used to examine the employees' perceptions of their leaders' emotionally intelligent personal and social skills on their job satisfaction. Findings in this study strongly suggest that collegial leaders demonstrate high levels of EI and collegiality in the working environment. These collegial leaders are equipped with personal and social skills which they use to contribute to the happiness and job satisfaction of their workers. Integral to the success and development of the collegial process is that employees feel that they are being nurtured in an open, warm and sincere environment. Clearly, a leader who demonstrates appropriate levels of emotionally intelligent personal and social skills will not only create a collegial working environment but will also thrive in one. The evidence emanating from this exploratory study confirms that there is a symbiotic relationship between emotional intelligence and collegial leadership. The emotionally intelligent collegial leader is a concept that extends far beyond a slogan and must become an integral part of organizational effectiveness and reform. It is inconceivable to speak about collegial leadership in the absence of emotional intelligence.
\end{abstract}

Keywords: Emotional Intelligence; Collegial Leadership; Social Skills; Personal Skills

\section{INTRODUCTION}

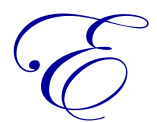

motional intelligence has become a vital part of how today's leaders meet the significant challenges they face (Childs, 2004). The culture of change in many organizations, whether in the private or public sector, is rife with anxiety, stress and ambiguity, and therefore should come as no surprise then that the most effective leaders are not the smartest in an IQ sense, but are those who combine intellectual brilliance with emotional intelligence (EI) (Fullan, 2007). As pointed out by Manz and Sims (2001), a fundamental reason for shifting employees from dependence to independence "is to improve bottom-line indicators, such as productivity and quality, while the follower benefits as well. Clearly, this would not be possible unless every employee was considered a true self-leader" (p.68-69). Also, as Cooper and Sawaf (1997) suggest, a work environment needs to be enthused by a satisfied and emotionally content workforce where rewards are intrinsic and the benefits are there for all to see in the guise of a happy and committed staff.

An effective and efficient working community is organized in a way that fosters an open flow of thoughts amongst workers, which also includes the upper echelons of management; stimulates critical reflection about analyses of ideas, policies, problems, and solutions; creates notions of what is universally acceptable as being the common good; and develops a concern for the rights and dignity of all workers (Kochan \& Reed, 2005; Short, 1998; Retallick \& Fink, 2002). It is expected that in such a setting, employers and employees would function together using democratic principles to improve organizational effectiveness. As Fullan (2007, p.9) points out:

The litmus test of all leadership is whether it mobilizes people's commitment to putting their energy into actions designed to improve things. It is individual commitment, but, above all, it is collective mobilization. 
Kouzes and Posner (1997) observed that credible leaders prefer to give away their power in the service of others and for a purpose larger than themselves. Such leaders accept and act on the paradox of power - we become the most powerful when we give our own power away (Kouzes \& Posner, 1997, p.185). Collegial leaders take the power that flows to them and connect it to the other members of their team. As pointed out by Kouzes and Posner (1997), when leaders share power with others, they demonstrate profound trust in and respect for others' abilities. Such leaders are most respected and most effective when they get things done with other people, not as traditional management myth has it - the highly controlling, tough-guy boss who simply prefers to get things done through other people (Hellriegel, Jackson, Slocum, Staude, Amos, Klopper, Louw \& Oosthuizen, 2006). The leader's ability to understand, identify and empathise with employees' emotions and then react appropriately are, according to Goleman (1996, p.119), integral factors which could help foster a feeling of job satisfaction amongst them:

Those who are emotionally intelligent can connect quite smoothly with people, be astute in reading their reactions and feelings, lead and organise, and handle disputes that are bound to flare up. They are the natural leaders - the people who can express the unspoken collective sentiment and articulate it so as to guide a group towards its goals. They are emotionally nourishing - they leave people in a good mood.

The empowerment of the staff in any organization depends on the devolution of power by leaders.

Traditional managers cling to power as an entitlement of their positions, whereas collegial leaders share their power base with their staff in order to flatten hierarchies (Kouzes \& Posner, 1997; Hellriegel et al., 2006). Empowered stakeholders therefore demonstrate a greater commitment to complete a task based on their increased sense of self-confidence, self-determination and personal effectiveness (Singh, 2005). Kochan and Reed (2005) state that democratic leadership requires individuals to adopt a collaborative approach that includes building a sense of community with both internal and external stakeholders. This involves sharing power with others which involves multiple groups of stakeholders in decision-making in meaningful ways. Evidently, the personal and social competences or behaviours associated with EI are clearly identifiable with the traits of collegial leadership as investigated in this study.

In order for employees to reach a level of job satisfaction that produces high levels of efficiency and effectiveness, Pascoe, Ali and Warne (2002, p.41) believe that the leader needs to demonstrate very specific emotionally intelligent social, personal, and collegial leadership skills:

The ability of the leader is to be able to identify and understand the emotions of others in the workplace, to be able to manage their own and others' positive and negative emotions, to effectively be able to control emotions in the workplace, to utilise emotional information when problem solving, and to be able to express their feelings to others is integral to the leader being effective at creating appropriate levels of job satisfaction.

It is aptly pointed out by Yukl (1998) that shared leadership not only involves leadership behaviours that build willing followers who commit themselves to the organization's objectives, but it also empowers followers to accomplish these objectives by their becoming leaders in their own fields of expertise. Enabling or empowering employees, as evident in this study, is an important aspect in establishing emotionally intelligent collaboration, as the willing and satisfied participation of workers may be the result of a leader's commitment to establishing a collegial environment as demonstrated by his/her EI behaviours (Singh, 2008). This paper therefore focuses on the relationship that exists between the social and emotional competences of leaders and their leadership style based on collegiality. The link between the perceived emotional intelligence of leaders and their leadership style in a collegial environment formed the basis of this research.

\section{COLLEGIALITY}

Collegiality is a collaborative process that entails the devolution of power to employees as relevant stakeholders in order for them to become an integral part of the organization's leadership processes that are guided by its shared vision (Sergiovanni, 1991). Collegiality is therefore considered a process of assimilation that involves encouraging personal visions to become part of a shared vision built on synergy (Singh \& Manser, 2002). This process is possible because collegial strategies tend to be more lateral or horizontal rather than being vertical and 
hierarchical, reflecting the view that all stakeholders should be involved in decision-making and "own" the outcome of discussions (Bush, 2003, p.70). As pointed out by Kouzes and Posner (1997, p.12), leaders "know that no one does his or her best when feeling weak, incompetent, or alienated; they know that those who are expected to produce the results must feel a sense of ownership."

In a collegial leadership environment, policies are determined and decisions are made through a process of discussion leading to consensus (Bush, 1993). There is power sharing based on expertise and mutual understanding of the organization's shared vision. The authority of expertise advocated by a collegial approach encourages employees to collaborate through shared values and establish decision-making skills based on their expertise. This implies that employees should mostly be held accountable when they are included in the decision-making process in a meaningful and collegial manner. Kochan and Reed (2005, p.72) describe the nature of collaborative (collegial) leadership as follows:

Collaborative leadership incorporates notions of reciprocity and working toward a common end. It is a relational experience that is defined, in practice, by those involved as they interrelate with one another and the context in which they operate. The ultimate goal of collaborative leadership is to create democratic learning communities in which power is shared and there is mutual belief in working together for the common good.

Members of a collaborative team need to be able to trust that the leader is supportive of their efforts and their input is regarded as meaningful (Singh, Manser \& Mestry, 2007). If such trust does not exist, there will be little chance of successful collaboration in an environment where sincerity is viewed with suspicion and doubt. Therefore, collegiality may be described as the way in which employees and their leaders share common values, common goals, accountability and a sense of trust built on a foundation of congeniality (Sergiovanni, 1991). When a relationship is an effective collaboration, leaders maximize their ability to get what they want or need from their staff members. After all, as Stein and Book (2001, p.112) point out, "no one is going to give you what you desire if they feel misunderstood or attacked. By contrast, every time others feel as if you're in tune with them, they feel validated. The emotional bond between you strengthens and the other person is more apt to work with, not against you."

Leadership, according to Kouzes and Posner (1997, p.30), is the "art of mobilizing others to want to struggle for shared aspirations." They (Kouzes \& Posner, 1997, p.31) state that "people in positions of authority can get other people to do something because of the power they wield, but leaders mobilize others to want to act because of the credibility they have." Therefore, collegial leadership focuses on the employees' capacity to play a participatory role in the leadership of the organization (Lofthouse, 1994; Senge, 1990; Singh \& Manser, 2002; Singh, Manser \& Mestry, 2007). Under these circumstances, collegial leadership should be viewed as a process that encourages and accommodates shared decision-making and shared leadership in the spirit of enabling workers to want to commit themselves positively to the vision of the organization (Singh, Manser \& Dali, 2012).

Kouzes and Posner (2001, p.85) point out that "leadership is a relationship between those who aspire to lead and those who choose to follow." They state that at the heart of this relationship is trust. Without trust, one simply cannot lead. Exemplary (collegial) leaders devote much of their time and effort to build sound relationships based on mutual respect and caring. Kouzes and Posner (2001, p.85) further point out that long before empowerment "was written into the popular vocabulary, leaders understood that only when their constituents feel strong, capable, and efficacious, and when they feel connected with one another, could they ever hope to get extraordinary things done."

Kouzes and Posner (1997) succinctly capture the essence of shared leadership by pointing out that leadership is not the private reserve of a few charismatic men and women. It is a process that ordinary people use when they are bringing forth the best from themselves and others. Liberate the leader in everyone and extraordinary things can happen in the organization. Kouzes and Posner (1997, p.16) point out that traditional "management teachings suggest that the job of management is primarily one of control - control of resources, including time, materials, and people." They point out that leaders "don't command and control; they serve and support." Collegial leaders can be classified as emancipators seeing that they contribute extensively to the creation of an environment in their organization for emancipation (Singh, 2005). 
Studies (Cherniss, 2000; Singh, 2008; Singh, Manser \& Dali, 2012; Veugelers \& Zijstra, 2002) in several organizations suggest that about two-thirds of the competences linked to superior performance are emotional qualities such as self-confidence, flexibility, persistence, empathy, and the ability to get along with others. This research data further indicates that in leadership positions, 90 percent of the competences necessary for success are social and personal in nature. Healthy and effective relationships, personal leadership, self-management, intrapersonal growth and development, and recognition of potential problems are essential elements for creating a positive and healthy learning climate (Merkowitz \& Earnest, 2006). Evidently, it is impossible to construe collegial leadership qualities without focusing on EI.

\section{WHAT IS EI?}

According to Bar-On, as quoted by Merkowitz and Earnest (2006), EI is an array of non-cognitive capabilities, competences, and skills that influence one's ability to succeed in coping with environmental demands and pressures. Broadly defined, EI addresses the emotional, personal, social, and survival dimensions of intelligence. EI and emotional skills develop over time, change throughout life, and relate to one's potential for performance, are process-oriented, and can be improved through training. Mayer and Salovey (1997, p.10) define EI as follows:

Emotional intelligence involves the ability to perceive accurately, appraise, and express emotion; the ability to access and/or generate feelings when they facilitate thought; the ability to understand emotion and emotional knowledge; and the ability to regulate emotions to promote emotional and intellectual growth.

EI is defined as a person's self-awareness, self-confidence, self-control, commitment and integrity, and a person's ability to communicate, influence, initiate change and accept change (Goleman, 1998). Studies have shown that EI impacts a leader's ability to be effective (Goleman, 1998). Three of the most important aspects of EI for a leader's ability to make effective decisions are self-awareness, communication and influence, and commitment and integrity. Leaders who do not develop their EI have difficulty in building good relationships with peers, subordinates, superiors and clients (Goleman, 1998). As pointed out by Bliss (2006), social skills are fundamental to EI. They include the ability to induce desirable responses in others by using effective diplomacy to persuade (influence); listen openly and send convincing messages (communicate); inspire and guide groups and individuals (leadership); nurture instrumental relationships (building bonds); work with others toward a shared goal (collaboration, cooperation); and create group synergy in pursuing collective goals.

A definition of EI offered by Orme (2001) refers to the ability to tune into one's own and others' emotions, identify and understand them, and then take appropriate action which, according to Orme (2001), may also be referred to as advanced common sense. EI is regarded as a major predictor of leadership success and is described by Sterret (2000) as that which differentiates exceptional performance from mediocre performance. It is a form of intelligence that comprises a set of non-cognitive abilities in the affective domain that influences one's ability to perceive or sense and understand the emotions of others (social EI) or to identify and manage one's own emotions (personal EI) in a manner that elicits appropriate responses and behaviour. It works synergistically with IQ rather than separate from it (Orme \& Cannon, 2000, p.1). It can be measured, learned and developed. It is regarded as a powerful motivational tool as it inspires confidence and trust in leaders who demonstrate high levels of EI. EI is defined by Fehd (2001) as the unique ability to know and act through means other than our intellect alone. It is comprised of personal and social skills or competencies that may dramatically influence human performance and hence have a marked effect on leadership, team and organizational effectiveness (Fehd, 2001).

What is clear from the above theoretical analysis is that EI is the ability of leaders to recognise, understand and regulate emotional behaviour on a social and personal level, in order to achieve desired optimum results and a sense of job satisfaction among their employees, in a collegial working environment.

\section{IQ VERSUS EI}

Research on leadership over the past two decades strongly suggests that the emotional intelligence of leaders matters twice as much as that of cognitive abilities such as IQ or technical expertise (Goleman, 2004). 
Emotional abilities are four times more important than IQ in determining leadership success (Sternberg, 1996). As pointed out by Northouse (2004), to manage means to accomplish activities and master routines while to lead means to influence others and create visions for change. Such researchers argue that managers and leaders are different types of people, managers being more reactive and less emotionally involved and leaders being more proactive and more emotionally involved. It is suggested by Sterret (2000) that the essential difference between IQ and EI lies in the distinction between the roles of the heart (emotion) and the head (cognition) in determining appropriate leadership behaviour.

Emotionally intelligent leaders experience a greater sense of well-being, improved relationships, happier employees and lower employee turnover, better team work, greater job satisfaction and a greater degree of success (Thilo, 2004). EI is the most important factor in achieving success seeing that high levels of achievement, success, and happiness are self-defined and directed (Merkowitz \& Earnest, 2006). Imagine looking through a pair of binoculars as a metaphor for leadership. One lens of the binoculars represents IQ while the other represents EI. Monocular vision, using only IQ, produces a very narrow view of the organization's horizon. Binocular vision, combining IQ with EI, produces a much clearer, broader and far reaching view. Exemplary leaders use both lenses to harness the best from their workers and sustain high performance from individuals, teams, and organizations (Human Performance Strategies, 2006).

Goleman (2004, p.4) points out that "when it comes to shaping our decisions and our actions, feeling counts every bit as much - and often more - than thought." He believes that we have gone too far in emphasizing the value and import of what IQ measures in human life since intelligence can come to nothing when the emotions hold sway. EI is not in opposition to IQ, but it is an extension of the human's potential to succeed in a people-oriented environment. Traditional cognitive intelligence (IQ) is combined with non-cognitive intelligence (EI) to help leaders perform at their best and inspire their followers to be successful and happy. A personal and emotional accountability system is essential for positive human development within the working environment.

\section{RELATIONSHIP BETWEEN EI AND COLLEGIAL LEADERSHIP}

Stein and Book (2001) point out that EI is not the antithesis of IQ, but rather a combination of both emotion and cognition. EI is not a replacement for on the job skills and intelligent task related logical thinking, but adds to the variety of skills that enable one to develop people through the enhancement of one's effective leadership skills (Caruso \& Salovey, 2003). Goleman (1998) suggests that the importance of EI can be gauged by the fact that there are certain situations, specifically in the areas of leadership where EI could be more effective than IQ in terms of personal communication, motivation, self-control, and empathetic behaviour. In other words, there are emotional factors that are not IQ related that play a relatively greater role in the acquisition of more favourable outcomes in the workplace when related specifically to relationships.

It is suggested by Bazerghi (2003a) that traditional cognitive intelligence (IQ) is combined with noncognitive intelligence (EI) to help leaders perform to their optimum and inspire their followers to be successful and happy. According to Bazerghi (2003b), this means that combining these two competences could form the foundation for leadership effectiveness, inspirational workers, high levels of achievement, and, ultimately, job satisfaction. EI is almost wholly responsible for the superior performance in leadership roles and when one is asks to consider what makes memorable leaders so special, one's response may correspond with their level of EI. Such leaders, Goleman (1996) claims, may be described as showing emotional competence because of their ability to utilise their EI effectively.

All leaders seem to share some common traits (Bliss, 2006). The first is a guiding vision or purpose. Leaders who have a clear idea of what they want to do professionally and personally will pursue the goal, regardless of the setbacks. The second characteristic is passion or enthusiasm and the ability to communicate that passion to others. Third is integrity, consisting of three ingredients - self-knowledge, candor, and maturity. Self-knowledge is about knowing one's strengths and weaknesses. Candor is being honest with yourself and is the key to knowing yourself. Maturity is the result of the lessons learned through following, while observing others, learning to be dedicated, and working with others. It is being truthful and never servile. The last two traits go hand in hand curiosity and daring. A leader wants to learn as much as possible and is willing to take risks (Bush, 1995). Bliss 
(2006) supports the notion that a leader has to have emotional intelligence to align personal and subordinate goals to accomplish organizational goals.

Belasco \& Stayer (1993) suggest a leader must implement four responsibilities at all organizational levels:

1. Transfer ownership for work to the people who do the work.

2. Create the environment where the transfer of ownership can take place, where each person wants to be responsible for his or her own performance. This entails painting a clear picture of what the organization believes great performance means for the organization and each person, focusing individuals on the few great performance factors, developing in each person the desire to be responsible for his or her performance, aligning organization systems and structures to send a clear message as to what is necessary for great performance, engaging each individual's heart, mind and hands in the business of the organization, and energizing people around the institution's focus.

3. Develop individual capability and competence.

4. Create conditions in the organization that challenge workers to continually learn to develop their workintegrated knowledge and skills.

These four principles align personal and organizational goals through emotional intelligence.

According to Gardner and Stough (2002, p.76), in order for employees to reach a level of job satisfaction that produces high levels of efficiency and effectiveness, the leader of the organization needs to demonstrate very specific emotionally intelligent competences and leadership skills:

The ability of the leader to be able to identify and understand the emotions of others in the workplace, to be able to manage their own and others' positive and negative emotions, to be able to control emotions in the workplace effectively, to utilise emotional information when problem-solving, and to be able to express their feelings to others, is integral to the leader being effective at creating appropriate levels of job satisfaction.

To be an effective collegial leader, it is imperative for such an incumbent to demonstrate emotionally intelligent competences or behaviours which can be classified as social or personal skills (Goleman, 2004; Singh, Manser \& Mestry, 2007; Singh, Manser \& Dali, 2012). In the social domain, it is imperative for a collegial leader to display skills directly related to leadership abilities, communication, conflict management, healthy relationships, empathy, and trust (Singh, Manser, \& Dali, 2012). In the personal domain, competences that play a crucial role in being an emotionally intelligent collegial leader are self-awareness, confidence, self-expression, self-control, adaptability, and optimism (Singh, Manser \& Dali, 2012). EI is a combination of these competences and, collectively, these skills contribute to a collegial leader's ability to self-regulate his or her own emotions and to appropriately identify and understand the emotional state of others. The collegial leadership style of leaders was investigated in terms of their emotionally intelligent personal and social skills.

\section{RESEARCH DESIGN}

The quantitative research method was used to determine the employees' perceptions of their leaders' personal and social skills in terms of their emotional intelligence and collegial leadership traits. A multi-respondent survey design was used. In such a design, the focus is on relationships between and among variables in a single group (Robson, 2002). Section A of the survey focused on the demographic variables of the participants while section B collected data on their job satisfaction. In section C, the questionnaire identified the following six (C1-C6) social skills that the respondents' employers should possess as collegial leaders: leadership (C1), communication (C2), conflict management (C3), relationships (C4), empathy (C5), and trust (5) which clearly evokes the collegial traits of the leaders' interpersonal collegial leadership style. The 55 questions posed asked the respondents to rate their leader according to the strength of the observable social EI characteristics in a collegial environment. Section D identified the following six (D1-D6) personal skills that the respondents' employers should possess as collegial leaders: self-awareness (D1), confidence (D2), self-expression (D3), self-control (D4), adaptability (D5), and optimism (D6), which clearly evoke the collegial traits of their leaders' personal leadership style. The 56 questions posed asked the respondents to rate their leaders according to the strength of each of the observable personal EI characteristics in a collegial environment. 
A sample of 474 employees from 200 organizations participated in this study. The subjects chosen to participate in the study were selected following a process, described by McMillan and Schumacher (2001), as nonprobability convenience sampling because the group of subjects was selected on the basis of their accessibility and availability in South Africa. The analysis and interpretation of the results in this paper focus on sections B, C and $\mathrm{D}$ of the questionnaire.

The value of Cronbach's Alpha was used to determine the reliability of the research; it verified that the research was reliable, that the questionnaire was consistent, and that the scores had insignificant error. The score of 0.923 for the overall reliability of sections B, C, and D was regarded as significant. Also, in order to ensure the content and construct validity of the questionnaire, a study of relevant literature on EI was undertaken. As part of the literature study for the research, the following models of EI were analysed in detail to draw up the questionnaire:

1. Personal and social EI skills (Fehd, 2001)

2. $\quad$ Scales of EI (Bar-On, 2000)

3. Emotional competence framework (Goleman, 1998)

4. Framework of emotional competencies (Boyatzis, Goleman \& Rhee, 2000)

5. $\quad$ Ability model of EI (Mayer, Salovey \& Caruso, 2000)

6. Intelligence reframed (Gardner, 1999)

7. $\quad$ K-A-B model of EI (Sterret, 2000)

8. Four cornerstones of EI (Cooper \& Sawaf, 1997)

These models of EI divide EI into skills, scales, competencies, abilities, traits, dimensions, behaviours, and cornerstones. Although the models are unique in certain aspects, there are significant similarities that exist. This process facilitated the identification of the twelve generic social (C1-C6) and personal (D1-D6) skills used in drawing up the questionnaire.

\section{RESULTS}

Two measures of relationship were used; namely, the Pearson Product - Moment Correlation $(r)$ and Spearman Rank ( $\rho$ or rho). The calculation of $r$ is to show the linear relationship between any two of the variables. According to Huysamen (1997), the calculation of $r$ and $\rho$ provides an objective measure of the strength of the relationship between the two variables. The level of significance for a two-tail test is 0.01 . It is pointed out by McMillan and Schumacher (2001) that the degree to which subjects maintain the same relative position on any two measures is shown by $\rho$. In other words, $\rho$ shows how much agreement exists between each of the variables. For each pair of variables, the coefficient of correlation value, the significance level, and the number of cases $(\mathrm{N})$ is given.

\section{Leaders' Emotionally Intelligent Social Skills}

Table 1 presents the Pearson Correlation Coefficients ( $r$ ) of the variables - job satisfaction (B) and all of the social skills (C1-C6). According to Huysamen (1997), the positive relationship indicated in Pearson's $(r)$ is significant @ $\mathrm{p}<0.01$. The Pearson correlation values are greater than zero, indicating a positive correlation between the social skills and the job satisfaction of workers in a collegial environment. When there is an increase in $\mathrm{C}, \mathrm{B}$ will also increase. This indicates that a significant relationship exists amongst the variables; namely, the social skills of leaders (C) and the job satisfaction of employees (B) in a collegial work environment. 
Table 1: Pearson Correlation Coefficients for B and C1-C6

\begin{tabular}{|c|c|c|c|c|c|c|c|c|}
\hline & & B & C1 & $\mathrm{C2}$ & C3 & $\mathrm{C4}$ & C5 & C6 \\
\hline B & $\begin{array}{l}\text { Pearson Correlation } \\
\text { Sig. (2-tailed) } \\
\text { N }\end{array}$ & $\begin{array}{l}1 \\
.000 \\
474\end{array}$ & $\begin{array}{l}.560^{* *} \\
.000 \\
474\end{array}$ & $\begin{array}{l}.538^{* *} \\
.000 \\
474\end{array}$ & $\begin{array}{l}.288^{* *} \\
.000 \\
474\end{array}$ & $\begin{array}{l}.537^{* *} \\
.000 \\
474\end{array}$ & $\begin{array}{l}.556^{* *} \\
.000 \\
474\end{array}$ & $\begin{array}{l}.574^{* *} \\
.000 \\
474\end{array}$ \\
\hline C1 & $\begin{array}{l}\text { Pearson Correlation } \\
\text { Sig. (2-tailed) } \\
\mathrm{N}\end{array}$ & $\begin{array}{l}.560^{* *} \\
.000 \\
474\end{array}$ & $\begin{array}{l}1 \\
.000 \\
474\end{array}$ & $\begin{array}{l}.588^{* *} \\
.000 \\
474\end{array}$ & $\begin{array}{l}.309^{* *} \\
.000 \\
474\end{array}$ & $\begin{array}{l}.599^{* *} \\
.000 \\
474\end{array}$ & $\begin{array}{l}.681^{* *} \\
.000 \\
474\end{array}$ & $\begin{array}{l}.611^{* *} \\
.000 \\
474\end{array}$ \\
\hline C2 & $\begin{array}{l}\text { Pearson Correlation } \\
\text { Sig. (2-tailed) } \\
\text { N }\end{array}$ & $\begin{array}{l}.538^{\text {** }} \\
.000 \\
474 \\
\end{array}$ & $\begin{array}{l}.588^{* *} \\
.000 \\
474 \\
\end{array}$ & $\begin{array}{l}1 \\
.000 \\
474 \\
\end{array}$ & $\begin{array}{l}.248 \\
.000 \\
474 \\
\end{array}$ & $\begin{array}{l}.662^{* *} \\
.000 \\
474 \\
\end{array}$ & $\begin{array}{l}.636^{* *} \\
.000 \\
474 \\
\end{array}$ & $\begin{array}{l}.664^{* *} \\
.000 \\
474 \\
\end{array}$ \\
\hline C3 & $\begin{array}{l}\text { Pearson Correlation } \\
\text { Sig. (2-tailed) } \\
\text { N }\end{array}$ & $\begin{array}{l}.288^{* * *} \\
.000 \\
474 \\
\end{array}$ & $\begin{array}{l}.309^{\text {*** }} \\
.000 \\
474 \\
\end{array}$ & $\begin{array}{l}.248^{* *} \\
.000 \\
474\end{array}$ & $\begin{array}{l}1 \\
.000 \\
474\end{array}$ & $\begin{array}{l}.244^{* *} \\
.000 \\
474\end{array}$ & $\begin{array}{l}.337^{\text {** }} \\
.000 \\
474\end{array}$ & $\begin{array}{l}.258^{* *} \\
.000 \\
474\end{array}$ \\
\hline $\mathrm{C4}$ & $\begin{array}{l}\text { Pearson Correlation } \\
\text { Sig. (2-tailed) } \\
\text { N }\end{array}$ & $\begin{array}{l}.537^{* *} \\
.000 \\
474\end{array}$ & $\begin{array}{l}.599^{* *} \\
.000 \\
474\end{array}$ & $\begin{array}{l}.662^{N *} \\
.000 \\
474\end{array}$ & $\begin{array}{l}.244 \\
.000 \\
474\end{array}$ & $\begin{array}{l}1 \\
.000 \\
474\end{array}$ & $\begin{array}{l}.705^{* *} \\
.000 \\
474\end{array}$ & $\begin{array}{l}.659^{* * *} \\
.000 \\
474\end{array}$ \\
\hline C5 & $\begin{array}{l}\text { Pearson Correlation } \\
\text { Sig. (2-tailed) } \\
\mathrm{N}\end{array}$ & $\begin{array}{l}.556^{* *} \\
.000 \\
474\end{array}$ & $\begin{array}{l}.681^{* *} \\
.000 \\
474\end{array}$ & $\begin{array}{l}.636^{* *} \\
.000 \\
474\end{array}$ & $\begin{array}{l}.337 \\
.000 \\
474\end{array}$ & $\begin{array}{l}.705^{* *} \\
.000 \\
474\end{array}$ & $\begin{array}{l}1 \\
.000 \\
474\end{array}$ & $\begin{array}{l}.739^{* * *} \\
.000 \\
474\end{array}$ \\
\hline C6 & $\begin{array}{l}\text { Pearson Correlation } \\
\text { Sig. (2- tailed) } \\
\text { N }\end{array}$ & $\begin{array}{l}.574^{* *} \\
.000 \\
474 \\
\end{array}$ & $\begin{array}{l}.611^{* * \pi} \\
.000 \\
474 \\
\end{array}$ & $\begin{array}{l}.664^{* *} \\
.000 \\
474 \\
\end{array}$ & $\begin{array}{l}.258 \\
.000 \\
474 \\
\end{array}$ & $\begin{array}{l}.659^{* *} \\
.000 \\
474 \\
\end{array}$ & $\begin{array}{l}.739^{* *} \\
.000 \\
474 \\
\end{array}$ & $\begin{array}{l}1 \\
.000 \\
474 \\
\end{array}$ \\
\hline
\end{tabular}

Correlation is significant at the 0.01 level (2-tailed)

Table 2 presents the findings of the Spearman Rank Correlation ( $\rho$ or rho) used to show the symmetric measures and the relationships between the variables job satisfaction (B) and all of the leaders' social skills (C 1 C6). According to Huysamen (1997), the positive relationship indicated in Spearman's @ p $<0.01$ is significant. The Spearman's correlation values are greater than zero, indicating a positive correlation between the variables. This indicates that a significant relationship exists amongst the variables. The correlation between $\mathrm{C} 3$ (conflict management) and $\mathrm{C} 1$ (leadership) is 0.309 with a highly significant $\mathrm{p}$-value of 0 , which is less than 0.01 , indicating that a significant relationship exists between $\mathrm{C} 3$ and $\mathrm{C} 1$. The Pearson correlation between C6 (trust) \& C5 (empathy) is 0.739 with a highly significant $p$-value of 0 , which is less than 0.01 , indicating that a significant relationship exists between C6 and C5. There is a large correlation between C3 \& C4, suggesting a strong relationship between conflict management and the relationship behaviour of the leader.

Table 2: Spearman's Correlation Coefficients for B and C1-C6

\begin{tabular}{|c|c|c|c|c|c|c|c|c|}
\hline & & B & C1 & $\mathrm{C} 2$ & C3 & $\mathrm{C} 4$ & C5 & C6 \\
\hline B & $\begin{array}{l}\text { Correlation Coefficient } \\
\text { Sig. (2-tailed) } \\
\text { N }\end{array}$ & $\begin{array}{l}1 \\
.000 \\
474\end{array}$ & $\begin{array}{l}.560^{2 *} \\
.000 \\
474\end{array}$ & $\begin{array}{l}.538^{* 1} \\
.000 \\
474\end{array}$ & $\begin{array}{l}.288^{* *} \\
.000 \\
474\end{array}$ & $\begin{array}{l}.537^{2 *} \\
.000 \\
474\end{array}$ & $\begin{array}{l}.556^{\text {Win }} \\
.000 \\
474\end{array}$ & $\begin{array}{l}.574^{* 17} \\
.000 \\
474\end{array}$ \\
\hline C1 & $\begin{array}{l}\text { Correlation Coefficient } \\
\text { Sig. (2-tailed) } \\
\text { N }\end{array}$ & $\begin{array}{l}.560^{* *} \\
.000 \\
474\end{array}$ & $\begin{array}{l}1 \\
.000 \\
474\end{array}$ & $\begin{array}{l}.588^{* * *} \\
.000 \\
474\end{array}$ & $\begin{array}{l}.309^{* *} \\
.000 \\
474\end{array}$ & $\begin{array}{l}.599^{* * *} \\
.000 \\
474\end{array}$ & $\begin{array}{l}.681^{* *} \\
.000 \\
474\end{array}$ & $\begin{array}{l}.611^{* *} \\
.000 \\
474\end{array}$ \\
\hline $\mathrm{C} 2$ & $\begin{array}{l}\text { Correlation Coefficient } \\
\text { Sig. (2-tailed) } \\
\text { N }\end{array}$ & $\begin{array}{l}.538^{* * 4} \\
.000 \\
474\end{array}$ & $\begin{array}{l}.588^{* *} \\
.000 \\
474\end{array}$ & $\begin{array}{l}1 \\
.000 \\
474\end{array}$ & $\begin{array}{l}.248^{* *} \\
.000 \\
474\end{array}$ & $\begin{array}{l}.662^{* *} \\
.000 \\
474\end{array}$ & $\begin{array}{l}.636^{* *} \\
.000 \\
474\end{array}$ & $\begin{array}{l}.664^{* *} \\
.000 \\
474\end{array}$ \\
\hline C3 & $\begin{array}{l}\text { Correlation Coefficient } \\
\text { Sig. (2-tailed) } \\
\text { N }\end{array}$ & $\begin{array}{l}.288^{* * *} \\
.000 \\
474\end{array}$ & $\begin{array}{l}.309^{* * *} \\
.000 \\
474 \\
\end{array}$ & $\begin{array}{l}.248^{\text {*** }} \\
.000 \\
474 \\
\end{array}$ & $\begin{array}{l}1 \\
.000 \\
474 \\
\end{array}$ & $\begin{array}{l}.244^{* * *} \\
.000 \\
474 \\
\end{array}$ & $\begin{array}{l}.337^{* * *} \\
.000 \\
474 \\
\end{array}$ & $\begin{array}{l}.258^{* * *} \\
.000 \\
474 \\
\end{array}$ \\
\hline $\mathrm{C4}$ & $\begin{array}{l}\text { Correlation Coefficient } \\
\text { Sig. (2-tailed) } \\
\text { N }\end{array}$ & $\begin{array}{l}.537^{* *} \\
.000 \\
474\end{array}$ & $\begin{array}{l}.599^{* *} \\
.000 \\
474\end{array}$ & $\begin{array}{l}.662^{* * *} \\
.000 \\
474\end{array}$ & $\begin{array}{l}.244^{* * * * *} \\
.000 \\
474\end{array}$ & $\begin{array}{l}1 \\
.000 \\
474\end{array}$ & $\begin{array}{l}.705^{* *} \\
.000 \\
474\end{array}$ & $\begin{array}{l}.659^{* *} \\
.000 \\
474\end{array}$ \\
\hline C5 & $\begin{array}{l}\text { Correlation Coefficient } \\
\text { Sig. (2-tailed) } \\
\text { N }\end{array}$ & $\begin{array}{l}.556 \\
.000 \\
474\end{array}$ & $\begin{array}{l}.681^{* \pi} \\
.000 \\
474\end{array}$ & $\begin{array}{l}.636^{* *} \\
.000 \\
474\end{array}$ & $\begin{array}{l}.337^{* *} \\
.000 \\
474\end{array}$ & $\begin{array}{l}.705^{* *} \\
.000 \\
474\end{array}$ & $\begin{array}{l}1 \\
.000 \\
474\end{array}$ & $\begin{array}{l}.739^{* *} \\
.000 \\
474\end{array}$ \\
\hline C6 & $\begin{array}{l}\text { Correlation Coefficient } \\
\text { Sig. (2- tailed) } \\
\text { N }\end{array}$ & $\begin{array}{l}.574^{* * *} \\
.000 \\
474\end{array}$ & $\begin{array}{l}.611^{* *} \\
.000 \\
474\end{array}$ & $\begin{array}{l}.664^{* *} \\
.000 \\
474\end{array}$ & $\begin{array}{l}.258^{* *} \\
.000 \\
474\end{array}$ & $\begin{array}{l}.659^{* *} \\
.000 \\
474\end{array}$ & $\begin{array}{l}.739^{* *} \\
.000 \\
474\end{array}$ & $\begin{array}{l}1 \\
.000 \\
474\end{array}$ \\
\hline
\end{tabular}

Correlation is significant at the 0.01 level (2-tailed) 
The correlation coefficients given in Tables 1 and 2 clearly show that the bivariate distribution of the variables has a positive and direct relationship. Both Pearson $r$ and Spearman $\rho$ indicate that the two variables namely, the job satisfaction of employees and their leaders' emotionally intelligent social skills rated by the respondents - are significant and therefore directly related in a collegial working environment.

\section{Leaders' Emotionally Intelligent Personal Skills}

Table 3 presents the findings of the Pearson's Product Moment Coefficient used to show the symmetric measures and the relationships between the variables. According to Huysamen (1997), the positive relationship indicated in Pearson's $\mathrm{r} @ \mathrm{p}<0.01$, as shown in Table 3, can be regarded as being significant. The Pearson correlation values, as indicated in Table 3 , are greater than 0 , indicating a positive correlation between the variables $\mathrm{B}$ and D1- D6 in a collegial working environment. Thus, a significant relationship exists among the variables. The Pearson correlation values are within the range of 0.50 to 1.0 suggesting a strong relationship between the variables. A significant relationship therefore exists between the variables with a highly significant $\mathrm{p}-$ value of 0 , which is less than 0.01 .

Table 3: Pearson Correlation Coefficients for B and D1-D6

\begin{tabular}{|c|c|c|c|c|c|c|c|c|}
\hline & & B & D1 & D2 & D3 & D4 & D5 & D6 \\
\hline B & $\begin{array}{l}\text { Pearson Correlation } \\
\text { Sig. (2-tailed) } \\
\text { N }\end{array}$ & $\begin{array}{l}1 \\
.000 \\
474\end{array}$ & $\begin{array}{l}.572^{* * *} \\
.000 \\
474\end{array}$ & $\begin{array}{l}.636^{* * *} \\
.000 \\
474\end{array}$ & $\begin{array}{l}.602^{* *} \\
.000 \\
474\end{array}$ & $\begin{array}{l}.524^{* * *} \\
.000 \\
474\end{array}$ & $\begin{array}{l}.556^{* *} \\
.000 \\
474\end{array}$ & $\begin{array}{l}.595^{* * *} \\
.000 \\
474\end{array}$ \\
\hline D1 & $\begin{array}{l}\text { Pearson Correlation } \\
\text { Sig. (2-tailed) } \\
\mathrm{N}\end{array}$ & $\begin{array}{l}.572^{\text {** }} \\
.000 \\
474 \\
\end{array}$ & $\begin{array}{l}1 \\
.000 \\
474 \\
\end{array}$ & $\begin{array}{l}.748^{* * *} \\
.000 \\
474 \\
\end{array}$ & $\begin{array}{l}.667^{* 6 /} \\
.000 \\
474 \\
\end{array}$ & $\begin{array}{l}.603^{* *} \\
.000 \\
474 \\
\end{array}$ & $\begin{array}{l}.600^{* * *} \\
.000 \\
474\end{array}$ & $\begin{array}{l}.657^{* * \%} \\
.000 \\
474\end{array}$ \\
\hline D2 & $\begin{array}{l}\text { Pearson Correlation } \\
\text { Sig. (2-tailed) } \\
\mathrm{N}\end{array}$ & $\begin{array}{l}.636^{* *} \\
.000 \\
474 \\
\end{array}$ & $\begin{array}{l}.748^{* * *} \\
.000 \\
474\end{array}$ & $\begin{array}{l}1 \\
.000 \\
474 \\
\end{array}$ & $\begin{array}{l}.663 \\
.000 \\
474 \\
\end{array}$ & $\begin{array}{l}.613^{* *} \\
.000 \\
474 \\
\end{array}$ & $\begin{array}{l}.652^{* *} \\
.000 \\
474\end{array}$ & $\begin{array}{l}.660^{* * *} \\
.000 \\
474\end{array}$ \\
\hline D3 & $\begin{array}{l}\text { Pearson Correlation } \\
\text { Sig. (2-tailed) } \\
\text { N }\end{array}$ & $\begin{array}{l}.602^{* * *} \\
.000 \\
474\end{array}$ & $\begin{array}{l}.667^{* * * 4} \\
.000 \\
474\end{array}$ & $\begin{array}{l}.663^{* *} \\
.000 \\
474\end{array}$ & $\begin{array}{l}1 \\
.000 \\
474\end{array}$ & $\begin{array}{l}.643^{* *} \\
.000 \\
474\end{array}$ & $\begin{array}{l}.610^{* *} \\
.000 \\
474\end{array}$ & $\begin{array}{l}.709^{* * *} \\
.000 \\
474\end{array}$ \\
\hline D4 & $\begin{array}{l}\text { Pearson Correlation } \\
\text { Sig. (2-tailed) } \\
\text { N }\end{array}$ & $\begin{array}{l}.524^{* *} \\
.000 \\
474\end{array}$ & $\begin{array}{l}.603^{* * *} \\
.000 \\
474\end{array}$ & $\begin{array}{l}.613^{* * *} \\
.000 \\
474\end{array}$ & $\begin{array}{l}.643^{* *} \\
.000 \\
474\end{array}$ & $\begin{array}{l}1 \\
.000 \\
474\end{array}$ & $\begin{array}{l}.648^{* * *} \\
.000 \\
474\end{array}$ & $\begin{array}{l}.633^{* * *} \\
.000 \\
474\end{array}$ \\
\hline D5 & $\begin{array}{l}\text { Pearson Correlation } \\
\text { Sig. (2-tailed) } \\
\text { N }\end{array}$ & $\begin{array}{l}.556^{* *} \\
.000 \\
474\end{array}$ & $\begin{array}{l}.600^{* *} \\
.000 \\
474\end{array}$ & $\begin{array}{l}.652^{* *} \\
.000 \\
474\end{array}$ & $\begin{array}{l}.610^{* * *} \\
.000 \\
474\end{array}$ & $\begin{array}{l}.648^{* *} \\
.000 \\
474\end{array}$ & $\begin{array}{l}1 \\
.000 \\
474\end{array}$ & $\begin{array}{l}.725^{* *} \\
.000 \\
474\end{array}$ \\
\hline D6 & $\begin{array}{l}\text { Pearson Correlation } \\
\text { Sig. (2- tailed) } \\
\text { N }\end{array}$ & $\begin{array}{l}.595^{\text {Nith }} \\
.000 \\
474\end{array}$ & $\begin{array}{l}.657^{2 * \pi} \\
.000 \\
474\end{array}$ & $\begin{array}{l}.660^{* m} \\
.000 \\
474\end{array}$ & $\begin{array}{l}.709^{* * F} \\
.000 \\
474\end{array}$ & $\begin{array}{l}.633^{* *} \\
.000 \\
474\end{array}$ & $\begin{array}{l}.725^{* *} \\
.000 \\
474\end{array}$ & $\begin{array}{l}1 \\
.000 \\
474\end{array}$ \\
\hline
\end{tabular}

Correlation is significant at the 0.01 level (2-tailed)

Table 4 presents the findings of the Spearman Rank Correlation $\rho$ used to show the symmetric measures and the relationships between the variables. The positive relationship indicated in Spearman's @ p < 0.01, as shown in Table 4, can, as Huysamen (1997) suggests, also be regarded as being statistically significant. The correlation coefficients presented in Tables 3 and 4 are comparable to those presented in Tables 1 and 2. They clearly show that the bivariate distribution of the two variables, the workers' sense of job satisfaction and their leaders' emotionally intelligent personal skills in a collegial environment have a positive and significant relationship. Both Pearson $r$ and Spearman $\rho$ indicate that the two variables are significant and therefore directly related. 
Table 4: Spearman's Correlation coefficients $\rho$ for B and D1-D6

\begin{tabular}{|c|c|c|c|c|c|c|c|c|}
\hline & & B & D1 & D2 & D3 & D4 & D5 & D6 \\
\hline B & $\begin{array}{l}\text { Correlation Coefficient } \\
\text { Sig. (2-tailed) } \\
\text { N }\end{array}$ & $\begin{array}{l}1 \\
.000 \\
474\end{array}$ & $\begin{array}{l}.572^{* * *} \\
.000 \\
474\end{array}$ & $\begin{array}{l}.636^{* *} \\
.000 \\
474\end{array}$ & $\begin{array}{l}.602^{* *} \\
.000 \\
474\end{array}$ & $\begin{array}{l}.524^{* * *} \\
.000 \\
474\end{array}$ & $\begin{array}{l}.556^{* *} \\
.000 \\
474\end{array}$ & $\begin{array}{l}.595^{* *} \\
.000 \\
474\end{array}$ \\
\hline D1 & $\begin{array}{l}\text { Correlation Coefficient } \\
\text { Sig. (2-tailed) } \\
\mathrm{N}\end{array}$ & $\begin{array}{l}.572^{* *} \\
.000 \\
474 \\
\end{array}$ & $\begin{array}{l}1 \\
.000 \\
474 \\
\end{array}$ & $\begin{array}{l}.748^{* * *} \\
.000 \\
474 \\
\end{array}$ & $\begin{array}{l}.667^{\text {** }} \\
.000 \\
474 \\
\end{array}$ & $\begin{array}{l}.603^{* * *} \\
.000 \\
474 \\
\end{array}$ & $\begin{array}{l}.600^{* * *} \\
.000 \\
474 \\
\end{array}$ & $\begin{array}{l}.657^{* 3 * * * 3} \\
.000 \\
474 \\
\end{array}$ \\
\hline D2 & $\begin{array}{l}\text { Correlation Coefficient } \\
\text { Sig. (2-tailed) } \\
\text { N }\end{array}$ & $\begin{array}{l}.636^{* * *} \\
.000 \\
474 \\
\end{array}$ & $\begin{array}{l}.748^{* * *} \\
.000 \\
474 \\
\end{array}$ & $\begin{array}{l}1 \\
.000 \\
474 \\
\end{array}$ & $\begin{array}{l}.248^{* *} \\
.000 \\
474 \\
\end{array}$ & $\begin{array}{l}.613^{* *} \\
.000 \\
474 \\
\end{array}$ & $\begin{array}{l}.652^{* *} \\
.000 \\
474 \\
\end{array}$ & $\begin{array}{l}.660^{* * *} \\
.000 \\
474 \\
\end{array}$ \\
\hline D3 & $\begin{array}{l}\text { Correlation Coefficient } \\
\text { Sig. (2-tailed) } \\
\text { N }\end{array}$ & $\begin{array}{l}.602^{* *} \\
.000 \\
474 \\
\end{array}$ & $\begin{array}{l}.667^{* * *} \\
.000 \\
474 \\
\end{array}$ & $\begin{array}{l}.663^{* *} \\
.000 \\
474\end{array}$ & $\begin{array}{l}1 \\
.000 \\
474\end{array}$ & $\begin{array}{l}.643^{* *} \\
.000 \\
474\end{array}$ & $\begin{array}{l}.610^{* *} \\
.000 \\
474\end{array}$ & $\begin{array}{l}.709^{* * *} \\
.000 \\
474\end{array}$ \\
\hline D4 & $\begin{array}{l}\text { Correlation Coefficient } \\
\text { Sig. (2-tailed) } \\
\text { N }\end{array}$ & $\begin{array}{l}.524^{* *} \\
.000 \\
474\end{array}$ & $\begin{array}{l}.603^{* *} \\
.000 \\
474\end{array}$ & $\begin{array}{l}.613^{* * 7} \\
.000 \\
474\end{array}$ & $\begin{array}{l}.643^{* *} \\
.000 \\
474\end{array}$ & $\begin{array}{l}1 \\
.000 \\
474\end{array}$ & $\begin{array}{l}.648^{* *} \\
.000 \\
474\end{array}$ & $\begin{array}{l}.633^{* * 9} \\
.000 \\
474\end{array}$ \\
\hline D5 & $\begin{array}{l}\text { Correlation Coefficient } \\
\text { Sig. (2-tailed) } \\
\mathrm{N}\end{array}$ & $\begin{array}{l}.556^{* *} \\
.000 \\
474\end{array}$ & $\begin{array}{l}.600^{* * *} \\
.000 \\
474\end{array}$ & $\begin{array}{l}.652^{* *} \\
.000 \\
474\end{array}$ & $\begin{array}{l}.610^{* * *} \\
.000 \\
474\end{array}$ & $\begin{array}{l}.648^{* * *} \\
.000 \\
474\end{array}$ & $\begin{array}{l}1 \\
.000 \\
474\end{array}$ & $\begin{array}{l}.725^{* * 6} \\
.000 \\
474\end{array}$ \\
\hline D6 & $\begin{array}{l}\text { Correlation Coefficient } \\
\text { Sig. (2- tailed) } \\
\text { N }\end{array}$ & $\begin{array}{l}.595^{\text {** }} \\
.000 \\
474 \\
\end{array}$ & $\begin{array}{l}.657^{* 3 *} \\
.000 \\
474 \\
\end{array}$ & $\begin{array}{l}.660^{*} \\
.000 \\
474\end{array}$ & $\begin{array}{l}.709^{* *} \\
.000 \\
474\end{array}$ & $\begin{array}{l}.633^{* * 3} \\
.000 \\
474\end{array}$ & $\begin{array}{l}.725^{*} \\
.000 \\
474\end{array}$ & $\begin{array}{l}1 \\
.000 \\
474 \\
\end{array}$ \\
\hline
\end{tabular}

Correlation is significant at the 0.01 level (2-tailed)

Furthermore, it can be seen from the scores in Table 5 that, with the exception of $\mathrm{C} 3$, the scores are skewed toward the maximum. The spread of the distribution of scores in B, C, and D, as reflected by the standard deviations, indicate that the distributions are positively skewed with little variance with one degree of freedom. Table 6 presents the variances, skewness and Kurtosis for sections B, C, and D which show if the respondents were normal in nature. The standard error of skewness indicates the normality of the statistics. The relation of skewness to its standard error is used to test for normality. Normality is present when at least $68 \%$ of the respondents' observations fall within a range of 1 standard deviation from the mean and $95 \%$ of the remaining scores fall within \pm 2 standard deviation points from the mean. It is evident from Table 6 that, with the exception of $\mathrm{C} 3$, the distribution does not vary from the normal.

Table 5: Descriptive Statistics - Mean, Standard Deviation and Degrees of Freedom

\begin{tabular}{|c|c|c|c|c|c|}
\hline & $\mathbf{N}$ & \multicolumn{2}{|c|}{ Mean } & Standard Deviation & Degrees of Freedom \\
\hline & Statistic & Statistic & Std. Error & Statistic & \\
\hline B & 474 & 1.68 & 0.021 & 0.4666 & 1 \\
\hline C1 & 474 & 1.65 & 0.022 & 0.477 & 1 \\
\hline $\mathrm{C2}$ & 474 & 1.74 & 0.020 & 0.436 & 1 \\
\hline $\mathbf{C 3}$ & 474 & 1.15 & 0.017 & 0.359 & 1 \\
\hline $\mathbf{C 4}$ & 474 & 1.71 & 0.021 & 0.454 & 1 \\
\hline$\overline{C 5}$ & 474 & 1.61 & 0.022 & 0.488 & 1 \\
\hline C6 & 474 & 1.69 & 0.021 & 0.463 & 1 \\
\hline D1 & 474 & 1.73 & 0.20 & 0.443 & 1 \\
\hline D2 & 474 & 1.72 & 0.021 & 0.452 & 1 \\
\hline D3 & 474 & 1.73 & 0.020 & 0.443 & 1 \\
\hline D4 & 474 & 1.64 & 0.022 & 0.481 & 1 \\
\hline D5 & 474 & 1.67 & 0.022 & 0.470 & 1 \\
\hline D6 & 474 & 1.69 & 0.021 & 0.465 & 1 \\
\hline
\end{tabular}


Table 6: Descriptive Statistics - Skewness and Kurtosis of the Distribution

\begin{tabular}{|l|c|c|c|c|c|}
\hline & Variance & \multicolumn{2}{|c|}{ Skewness } & \multicolumn{2}{c|}{ Kurtosis } \\
\hline & Statistic & Statistic & Std. Error & Statistic & -1.379 \\
\hline B & 0.217 & -0.792 & 0.112 & -1.597 & 0.224 \\
\hline C1 & 0.227 & -0.640 & 0.112 & -0.735 & 0.224 \\
\hline C2 & 0.191 & -1.126 & 0.112 & 1.794 & 0.224 \\
\hline C3 & 0.129 & 1.946 & 0.112 & -1.133 & 0.224 \\
\hline C4 & 0.206 & -0.934 & 0.112 & -1.796 & 0.224 \\
\hline C5 & 0.238 & -0.460 & 0.112 & -1.327 & 0.224 \\
\hline C6 & 0.214 & -0.824 & 0.112 & -0.899 & 0.224 \\
\hline D1 & 0.197 & -1.051 & 0.112 & -1.089 & 0.224 \\
\hline D2 & 0.204 & -0.957 & 0.112 & -0.899 & 0.224 \\
\hline D3 & 0.197 & -1.051 & 0.112 & -1.680 & 0.224 \\
\hline D4 & 0.232 & -0.572 & 0.112 & -1.474 & 0.224 \\
\hline D5 & 0.221 & -0.730 & 0.112 & -1.362 & 0.224 \\
\hline D6 & 0.216 & -0.802 & 0.112 & & 0.224 \\
\hline
\end{tabular}

The number of responses indicating that each of the EI skills of a leader would have an influence on an employee's sense of job satisfaction ranged from 93\% (a leader's sense of self-awareness) to $99 \%$ (a leader's ability to be adaptable). As the responses are significantly similar, it can be stated that the respondents indicated that the perceived EI of a leader would influence an employee's sense of job satisfaction in a collegial work environment.

It can be deduced from the results of the study that there is a significant correlation between the job satisfaction of employees and their leaders' EI in a collegial work environment that contributes to organizational effectiveness. The respondents' expectations of leaders indicate that in order for them to experience job satisfaction, their leaders need to demonstrate both social and personal skills. As aptly pointed out in this study, the leaders' social and personal skills serve as intervening variables that affect the job satisfaction of employees and they are integral to the creation of a positive staff morale. Respondents who indicated that they are satisfied at their place of work rated their leader's EI as being high. They also believe that a leader's EI influences their sense of job satisfaction. The respondents' support for a leadership style that offers them the opportunity to be actively involved in creative decision-making strategies, rather than be subjected to an autocratic style of control, was clearly spelled out in their responses. The link between collegiality and meaningful personal and social emotionally intelligent skills is significant and directly related to a sense of job satisfaction amongst all employees, as evident in this study.

\section{CONCLUSION}

Results in this study strongly suggest that collegial leaders demonstrate high levels of EI and collegiality in the working environment. Empathy, empowerment and emancipation underpin joint decision-making and shared leadership in this highly functional, collegial work environment. They are equipped with personal and social skills which they utilise to contribute to the happiness and job satisfaction of fellow workers in the environment. Integral to the success and development of the collegial process is that employees are happy and motivated and they feel that they are being nurtured in an open, warm and sincere environment. Hence, a collegial environment needs to be created within the organization for employees to be able to engage in self-criticism, self-planning and self-problemsolving. They must be empowered to question traditional approaches and have the capacity to emancipate themselves from conventional restrictive practices. This will enable them to be free to actually take part in the decision-making process as dictated by their ability and to accept ownership of the goals of the organization through joint decision-making.

Being a leader requires such a person to promote an organizational passion for quality. It is a myth that leaders are entrusted with absolute power to manage all the resources of their organizations. Collegiality forms the backbone of shared leadership. Collegiality is about sharing responsibilities and being accountable for one's actions. This should be the goal of all emotionally intelligent leaders. Nothing less should be acceptable. The emotionally intelligent collegial leader is a concept that extends far beyond a slogan and must become an integral part of reform for organizations. It is therefore inconceivable, as the research strongly shows, to speak about collegial leadership in the absence of emotional intelligence. The evidence emanating from this exploratory study confirms that there is a symbiotic relationship between emotional intelligence and collegial leadership. Clearly, a leader who demonstrates 
appropriate levels of emotionally intelligent personal and social skills will not only create a collegial work environment, but will also thrive in one. It can therefore be concluded that the emotionally intelligent personal and social skills of leaders in a collegial working environment can meaningfully contribute to the job satisfaction of their employees.

\section{AUTHOR INFORMATION}

Professor Prakash Singh is a professor of education at the Nelson Mandela Metropolitan University in Port Elizabeth, South Africa. He is currently a rated researcher by the National Research Foundation in South Africa, and is a former Senior Research Fulbright scholar. Professor Singh is the author of Innovative Strategies to Develop Better Schools. He has also published widely in peer reviewed journals, focusing on leadership and management, organisational effectiveness, emotional intelligence, tobephobia, and curriculum development. Professor Singh has presented numerous papers at international conferences. E-mail: Prakash.Singh@nmmu.ac.za

\section{REFERENCES}

1. $\quad$ Bar-On, R. (2000). Handbook of emotional intelligence. San Francisco: Jossey Bass.

2. Bazerghi, E. (2003a). Emotionally intelligent leadership. Retrieved from: www.humanperformancestrategies.com

3. $\quad$ Bazerghi, E. (2003b). Organizational effectiveness. Retrieved from: www.humanperformancestrategies.com

4. Belasco, J.A. \& Stayer, R.C. (1993). Flight of the buffalo: Soaring to excellence, learning to let employees lead. New York: Warner.

5. Bliss, S.E. (2006). The affect of emotional intelligence on a modern organizational leader's ability to make effective decisions. Retrieved from: http://eqi.org/mgtpaper.htm

6. Boyatzis, R., Goleman, D. \& Rhee, K. (2000). Clustering competence in emotional intelligence: Insights from the emotional intelligence inventory. In R. Bar-On \& J. Parker (Eds.), Handbook of emotional intelligence. San Francisco: Jossey-Bass.

7. Bush, T. (1993). Exploring collegiality: theory, process and structure in managing schools. Milton Keynes: Open University.

8. $\quad$ Bush, T. (1995). Theories of educational management. London: Paul Chapman.

9. Bush, T. (2003). Organizational structure. In M. Thurlow, T. Bush \& M. Coleman M (Eds.), Leadership and strategic management in South African schools. London: Commonwealth Secretariat.

10. Caruso, D. \& Salovey, P. (2003). The emotionally intelligent manager. San Francisco: Jossey-Bass.

11. Cherniss, C. (2000). Social and emotional competence in the workplace. In R. Bar-On \& J.D.A Parker, (Eds.), The handbook of emotional intelligence. San Francisco: Jossey-Bass.

12. Childs, R. (2004). Emotional intelligence and leadership. Retrieved from:http://www.teamtechnology.co.uk/emotional-intelligence.html

13. Cooper, R. \& Sawaf, A. (1997). Executive EQ. emotional intelligence in business. London: Texere.

14. Fehd, L. (2001). Emotional intelligence: an executive handbook. Austin: Good Pages.

15. Fullan, M. (2007). Leading in a culture of change. San Francisco: Jossey-Bass.

16. Gardner, H. 1999. Intelligence reframed. New York: Basic Books.

17. Gardner, L. \& Stough, C. (2002). Examining the relationship between leadership and emotional intelligence in senior level managers. Leadership and Organization Development Journal, 23:68-78.

18. Goleman, D. (1996). Emotional intelligence. London: Bloomsbury.

19. Goleman, D. (1998). Working with emotional intelligence. New York: Bantam Books.

20. Goleman, D. (2004). Emotional intelligence and working with emotional intelligence. London: Bloomsbury.

21. Hellriegel, D., Jackson, S.E., Slocum, J., Staude, G., Amos, T., Klopper, H.B., Louw, L. \& Oosthuizen, T. (2006). Management. Oxford: Cape Town.

22. Human Performance Strategies. (2006). Emotional intelligence. Retrieved from:http://humanperformancestrategies.com/ei.htm

23. Huysamen, G.K. (1997). Descriptive statistics for the social and behavioural sciences. Cape Town: Creda. 
24. Kochan, F.K. \& Reed, C.J. (2005). Collaborative leadership, community building, and democracy in public education. In W.E. Fenwick (Ed.), The Sage handbook of educational leadership. London: Sage.

25. Kouzes, J.M. \& Posner, B.Z. (1997). The leadership challenge. San Francisco: Jossey-Bass.

26. Kouzes, J.M. \& Posner, B.Z. (2001). Bringing leadership lessons from the past into the future. In W. Bennis, G.M. Spreitzer \& T.G. Cummings (Eds.), The future of leadership. San Francisco: Jossey-Bass.

27. Lofthouse, M. (1994). Managing learning. In T. Bush \& J. West-Burnham (Eds.), The principles of educational management. London:Pitman.

28. Manser, P.G. (2005). The influence of school principals' emotionally intelligent behaviours on the job satisfaction of educators in the Eastern Cape. Unpublished PhD thesis. Port Elizabeth: Nelson Mandela Metropolitan University.

29. Manz, C.C. \& Sims, H.P. (2001). The new super leadership. San Francisco: Berrett-Koehler.

30. Mayer, J.D. \& Salovey, P. (1997). What is emotional intelligence. In P. Salovey \& D. Sluyter (Eds.), Emotional development and emotional intelligence. New York: Basic Books.

31. Mayer, J.D., Salovey, P. \& Caruso, D. (2000). Competing models of emotional intelligence. In R.J. Sterrenberg (Ed.), Handbook of emotional intelligence. New York: Cambridge University Press.

32. McMillan, J. H. \& Schumacher, S. (2001). Research in education. New York: Longman.

33. Merkowitz, R.F. \& Earnest, G.W. (2006). Emotional intelligence: a pathway to self-understanding and improved leadership capacities. Retrieved from: http://www.joe.org/joe/2006august/iw3.shtml

34. Northouse, P.G. (2004). Leadership: theory and practice. London: Sage.

35. Orme, G. (2001). Emotionally intelligent living. London: Crown House

36. Orme, G. \& Cannon, K. (2000). Everything you wanted to know about implementing an emotional intelligence programme (but were afraid to ask). EQ Network. Retrieved from: www.Eiuk.com

37. Pascoe, C., Ali, I.M. \& Warne, L. (2002). Yet another role for job satisfaction and work motivation Enabler of knowledge creation and knowledge sharing. Insite, June, 39-48.

38. Retallick, J. \& Fink, D. (2002). Framing leadership: Contributions and impediments to educational change. International Journal of Leadership in Education, 5(20): 91-104.

39. Robson, C. (2002). Real world research: a resource for social scientists and practitioner-researchers. Oxford: Blackwell.

40. Senge, P. (1990). The fifth discipline: the art and practice of the learning organization. Perth: Random House.

41. Sergiovanni, T.J. (1991). The principalship: a reflective practice perspective. Boston: Allyn and Bacon.

42. Short, P.M. (1998). Empowering leadership. Contemporary Education, 69:70-74.

43. Singh, P. (2005). Use of the collegial leadership model of emancipation to transform traditional management practices in secondary schools. South African Journal of Education, 25(1):11-18.

44. Singh, P. (2008). Emotional intelligence begets collegial leadership in education. The International Journal of Learning, 15(1):73-88.

45. Singh, P. \& Manser, P. (2002). Collegiality in education: a case study. South African Journal of Education, 22(1):56-64.

46. Singh, P. \& Manser, P. (2006). Effects of school principals emotionally intelligent behaviours on the job satisfaction of educators in the Eastern Cape. Unpublished research.

47. Singh, P., Manser, P. \& Mestry, R. (2007). Importance of emotional intelligence in conceptualizing collegial leadership in education. South African Journal of Education, 27(3): 541-563.

48. Singh, P., Manser, P. \& Dali, C. (2012). Principal leadership. Unpublished research.

49. Stein, S.J. \& Book, H.E. (2001). The EQ edge: Emotional intelligence and your success. New York: Stoddart.

50. $\quad$ Sternberg, R. (1996). Successful intelligence. New York: Simon \& Schuster.

51. Sterret, A.S. (2000). The manager's pocket guide to emotional intelligence. Massachusetts: HRD Press.

52. Thilo, J.L. (2004). Emotional intelligence and leadership in the ASC. American Association of Ambulatory Surgery Centers. Retrieved from: http://www.aaasc.org/features/monitor2003/FEA_030903_EmotionalIntelligenceLeadership. html

53. Veugelers, W. \& Zijlstra, H. (2002). What goes on in a network? Some Dutch experiences. International Journal of Leadership in Education, 5(2):175-186.

54. Yukl, G. (1998). Leadership in organizations. Saddle River: Prentice Hall. 
NOTES 